\title{
SUULINE RELATIIVLAUSE VIITEVAHENDINA ${ }^{1}$
}

\author{
RENATE PAJUSALU
}

\begin{abstract}
Annotatsioon. Artiklis käsitletakse eesti suuliste relatiivlausete toimimist viitevahendina. Materjaliks on 403 relatiivlauset, mis pärinevad Tartu Ülikooli suulise kõne korpuse institutsionaalsetest ja argivestlustest. Artikli põhifookuses on relatiivlause ja selle põhja koostöö viitamisel erinevates kontekstides, eelkõige lähtuvalt sellest, kas referent on juba varem tuttav või luuakse see relatiivlauset kasutades. Uuritud restriktiivsed ja mitterestriktiivsed relatiivlaused jagunevad selle alusel omakorda tüüpidesse, millel on oma funktsioon viitesuhetes ja vestluse sisu arenemises. See, kas relatiivlause põhi sisaldab määratlejaid, ei määra küll üheselt relatiivlause tüüpi, kuid on siiski oluline tegur relatiivlause referentse rolli mõistmisel.
\end{abstract}

Võtmesõnad: relatiivlause, referentsus, nimisõnafraas, määratlejad

\section{Sissejuhatus}

\subsection{Relatiivlause määratlusest}

Üks keelelise suhtluse põhiüksuseid on nimisõnafraas, millega viidatakse kõne all olevatele isikutele, asjadele ja nähtustele. Nimisõnafraas võib koosneda ainult asesõnast või nimisõnast või olla erineval viisil laiendatud. Nimisõna saab laiendada omadussõnade ja määratlejatega, aga ka relatiivlausega. Nii võib samale referendile viidata näiteks fraasidega tema, Mari, see naabritüdruk või see pikk naabritüdruk, kes hiljuti naaberkorterisse kolis. Viimasel juhul on fraas see pikk naabritüdruk saanud laienduseks relatiivlause, mis lisab pealausesse (milline see ka poleks) hoopis teise sündmuse: hiljutise kolimise (vt nt Keenan 1985; Comrie 1989; Givón 1983, 2005). Keeletüpoloogias mõistetakse relatiivlause all mõnikord

\footnotetext{
Artikli valmimist on toetanud Euroopa Liidu regionaalarengu fond (Eesti-uuringute Tippkeskus).
} 
ka muid konstruktsioone (vt nt Velupillai 2012: 323-325), milles nimisõnafraasi laiendab näiteks partitsiiptarind (nt eile loetud raamat, raamatu toonud sõber). Sellisest laiemast vaatenurgast on lähtunud näiteks Ann Pikver (1988) eesti keele relatiivlausete tüpoloogilises ülevaates. Siinses artiklis käsitlen siiski ainult kõrvallauselisi relatiivlauseid, vaadeldes eelkõige nende rolli referentide moodustumisel.

Relatiivlause on eesti keele käsitlustes defineeritud kui relatiivpronoomenist või -adverbist sidendiga algav kõrvallause, mis laiendab nimisõna-, kvantori- või adverbifraasi või mõnikord pealauset tervikuna (Erelt 2017: 738 , vt näited 1 ja 2). Sellist relatiivlause konstruktsiooni on nähtud omasena kogu Läänemere areaalile (Dahl, Koptevskaja-Tamm 2001).

(1) Too mulle raamat, mida eile lugesid! ${ }^{2}$

(2) Kohtusin meie ühise tuttava Mariga, kes tõi mulle raamatu.

Relatiivlausel on väidetud olevat kaks põhifunktsiooni: piiritleda põhjaga esitatud fraasi referent või anda selle kohta lisainfot. Näites (1) ei tea me, millist raamatut kõneleja mõtleb, kuni ta pole seda relatiivlausega täpsustanud. Näites (2) on aga Mari juba varem definiitne ja relatiivlause ei ole tema tuvastamise teenistuses. Vastavalt on relatiivlauseid liigitatud restriktiivseteks ehk piiritlevateks ja mitterestriktiivseteks ehk täpsustavateks ehk lisavateks ehk apositiivseteks (nt Keenan 1985; Comrie 1989; Andrews 2007; Loock 2007; Erelt 2017: 740). Mõnes tüpoloogilises käsitluses on relatiivlauseteks peetud ainult restriktiivseid relatiivlauseid, väites, et mitteidentifitseerivad laused on hoopis teine konstruktsioon (Andrews 2007), kuid see seisukoht ei ole eriti laialt levinud. Ka eesti keele kohta on väidetud, et just restriktiivne relatiivlause on prototüüpne (Erelt 2004: 407). Vahel jagatakse sarnaselt relatiivlausega ka kõiki nimisõna laiendeid restriktiivseteks ja mitterestriktiivseteks (vt nt Givón 2005: 135).

Nagu paljud relatiivlause uurijad juba varemgi on väitnud, on restriktiivsete ja mitterestriktiivsete relatiivlausete vahel sageli raske või võimatu vahet teha (Comrie 1989; Lindström 2004; Visapää 2012). Juhul, kui katselistes uurimustes tahetakse luua täiesti ühemõtteliselt restriktiivset relatiivlauset, on näiteks kasutatud kahte sama tüüpi korraga nähtaval olevat referenti (nt kaks karukuju, kellest ühel on pang kaelas, teisel ei ole), millest relatiivlausega viidatakse ühele neist kahest (karu, kellel on pang kaelas; vt nt Schubö jt 2015). Seda tüüpi selgelt restriktiivseid

${ }^{2}$ Siin ja edaspidi märgib kursiiv relatiivlauset ja selle põhja. 
relatiivlauseid esines palju ka eestikeelses poolkatselises uurimuses, kus kõnelejad pidid rääkima kahest kindlaks määratud ja pidevalt nähtaval olevast majast (Pajusalu jt 2018). Need on spontaanses dialoogis siiski üsna haruldased olukorrad.

Kuigi klassikalised relatiivlause käsitlused põhinevad eelkõige kirjutatud keelel, on relatiivlauseid analüüsitud ka suulises suhtluses. Helasvuo (1993) on vaadelnud relatiivlauseid katseliselt toodetud soomekeelsetes suulistes narratiivides, mis andis võimaluse näha varasema relatiivlausete liigituse nõrku külgi (vt allpool). Suulise suhtluse analüüs on näidanud, et relatiivlause võib olla tingitud partneri arusaamatusest ja aidata referenti identifitseerida (nn referentne parandus) või mitte seostuda partneri (mitte)mõistmisega, vaid jätkata mõtet, lisades uue predikatsiooni juba tuntud referendile (nn referentne lisandus, vt Stoenica, Pekarek Dohler 2020). Relatiivlause võib olla sündinud kahe vestleja koostöös näiteks nii, et kõneleja lisab ise nimisõnafraasile täpsustava relatiivlause pärast liiga pikka pausi, kuid relatiivlause võib lisada ka vestluspartner (Stoenica jt 2020).

Relatiivlausete esinemist on seotud ka tekstitüübiga. Soome keele puhul on leitud, et keskmiselt 10\% lausetest sisaldab relatiivlauset, kuid see sõltub päris palju tekstitüübist (vt ülevaadet Visapää 2012). On ka arvatud, et mida kirjeldavam ja arutlevam on tekst, seda rohkem on seal relatiivlauseid (Pääkkönen 1988). Visapää (2012) on jõudnud järelduseni, et ka relatiivlausete jagunemine restriktiivsete ja mitterestriktiivsete interpretatsioonide vahel on tekstitüübiti väga erinev. Sama on selgunud, võrreldes eesti keele relatiivlauseid nähtaval olevate referentide kirjeldustes ja narratiivides: kuigi protsendiliselt oli relatiivlauseid mõlemas tekstitüübis enam-vähem samapalju, on kirjelduste relatiivlaused peaaegu alati restriktiivsed ja moodustavad lahktarindeid, narratiivides aga leidub palju rohkem mitterestriktiivseid relatiivlauseid ja nende hulgas on väga vähe lahktarindeid (Pajusalu jt 2018).

Eesti keele spontaanse suulise suhtluse relatiivlauseid on varem uurinud Liina Lindström (2004), analüüsides relatiivlausete sõnajärge. Lindström jõudis muu hulgas selleni, et kuigi restriktiivsete ja mitterestriktiivsete relatiivlausete piir on hägus, võib siiski öelda, et suulises eesti keeles on restriktiivseid relatiivlauseid rohkem kui mitterestriktiivseid (vastavalt 63\% ja 37\%). Suulisel keelel põhineb ka Hanna Poogi uurimus relatiivpronoomenitest eesti murretes (Pook 2019). Siinkirjutaja teada 
pole aga suulise eesti keele relatiivlauseid uuritud nende põhja struktuuri ja infostaatust relatiivlause funktsiooniga sidudes.

\subsection{Relatiivlause tõlgendamist mõjutavad tegurid}

Relatiivlause funktsiooni tõlgendamine on seotud kogu kontekstiga, aga eriti tihedalt fraasiga, mida ta süntaktiliselt laiendab. Suuline vestlus on partnerite ajas toimuv koostegevus ning tähendused tekivad ja muutuvad pidevalt. Referente luuakse ja muudetakse vestluse käigus (nt Kibrik 2011). Iga referendi puhul, millest kõneldakse, on oluline nii selle referentne staatus kõnelemise hetkel (vt nt Gundel jt 2019) kui kõik teadmised, mis kõnelejatel sellest referendist on. Seetõttu on erinevate kontekstide hulk väga suur ja mõnikord ongi uurimustes piirdutud mingit ühte tüüpi fraase laiendavate relatiivlausetega. Näiteks Jerra Lui Busch ja Felix Schuman (2016) vaatlevad ebaspetsiifilisi nimisõnafraase laiendavate relatiivlausete tõlgendust. Kuna eesti keele suulise kõne relatiivlausete üldiseloomustust siiani pole, püüan siiski anda võimalikult täieliku ülevaate materjalis esinevatest relatiivlause põhja juhtudest.

Kui relatiivlause põhi on definiitne (nagu meie ühine tuttav Mari näites 2), ei saagi seda relatiivlausega tuvastada, sest ta juba on tuvastatud, ja relatiivlause funktsiooniks saab olla ainult uue info lisamine. Mõnikord ongi restriktiivne ja mitterestriktiivne relatiivlause defineeritud vastavalt põhja indefiniitsuse ja definiitsuse kaudu. Näiteks Edward Keenan (1985) on restriktiivsete ja mitterestriktiivsete relatiivlausete põhiliseks eristavaks näitajaks pidanud seda, et mitterestriktiivsete relatiivlausete põhi on definiitne (nt meie ühine tuttav Mari näites 2). Marja-Liisa Helasvuo (1993) on leidnud, et selline jaotus jätab esitleva lause indefiniitset nimisõnafraasi laiendavad relatiivlaused justkui kahe rühma vahele (nt seal oli üks mees, kes korjas pirne, vt Helasvuo 1993: 169).

Piiritlev (restriktiivne) relatiivlause võimaldab võimalike referentide hulgast valida selle, millest parasjagu räägitakse. Näites (3) küsib kõneleja infotelefonilt telefoninumbrit, millest on juba varem räägitud (sellele osutab verbivorm oli), ja määratleb selle relatiivlausega mis oli tasuline. Tegemist on selge restriktiivse relatiivlause näitega: varem on infotelefoni klient saanud juba mitu telefoninumbrit ja palub nüüd korrata nende hulgast seda, mis on tasuline. Restriktiivseid relatiivlauseid pole üldjuhul rühmadeks jaotatud, nagu oleksid nad kõik ühesuguste funktsioonidega. 
Leidub siiski ka üksikuid uurimusi, milles on näidatud, et restriktiivne relatiivlause võib omada ka muid funktsioone kui ainult referendi määratlemine (vt ka Hoek jt 2020).

(3) 'öelge 'kuidas see 'telefoninumber oli mis on 'tasuline ${ }^{3}$

Mitterestriktiivseid relatiivlauseid ehk selliseid, mille funktsioon ei ole piiritleda nimisõnafraasi referenti, on omakorda jagatud a) öeldu relevantsust osutavateks ja/või omadusi esitavateks, b) oma suhtumist väljendavateks ja c) jutustust jätkavateks (Loock 2007, vt ka Visapää 2012). Näites (4) on relatiivlause funktsiooniks anda uut infot nimetatud linna kohta pigem seda iseloomustades või, nagu Loock (2007) on öelnud, relevantseks osutades (mis on kuulus oma vana Rooma villa poolest). Näide (5) väljendab kõneleja suhtumist viidatud vaatamisväärsusesse, lisades väitele subjektiivsust diskursusemarkeriga ma arvan (mis on huvitav ma arvan: lastele kui ka täiskasvanutele). Näited (4) ja (5) on mitterestriktiivsete relatiivlausete kohta, mille funktsioon ei ole referenti piiritleda, sest see on niigi definiitne. Näites (6) laiendab relatiivlause varem nimetamata restorani, kuid ei piiritle siinkirjutaja hinnangul võimalike referentide hulka, vaid jätkab info andmist reisi toitlustuse kohta ehk kõne all olevat teemat. Siiski on just näide (6) selline, mis tekitab interpretatsiooniprobleeme, sest puhtloogiliselt võttes võiks ju mõelda ka nii, et relatiivlause piiritleb kõikidest maailma restoranidest just selle, milles turiste toitma hakatakse (ja sel juhul liigituks restriktiivsete relatiivlausete hulka).

(4) 'järgmisel Sitsiilias viibimise 'päeval on siis n- 'nimekirjas Biatsa Armeriina'linn,@mis on 'kuulus omavana Rooma'villa poolest. @

(5) siis on 'Arktika 'muuseum mis=on huvitav ma arvan: 'lastele kui ka 'täiskasvanutele

(6) seal on nagu 'restoran kus siis 'toidetakse kaks korda 'päevas.

Üsna tüüpiline juhtum on aga ka selline, kus pealauses on indefiniitne fraas, mille nimetamisega tekib referent, kes või mis paigaldatakse suhtlejate viitevõrgustikku teiste parajasti aktiveeritud referentide hulka (vt ka Helasvuo 1993). Järgnev relatiivlause annab aga kohe lisainfot. Näidet (7) võib pidada restriktiivseks, kui käsitleda seda ühe viitamisena (üks vana inimene, kes on ...), ja infot lisavaks, kui käsitleda seda kahe viitamisena: kõigepealt

3 Näidete litereering on muutmatult pärit suulise kõne korpusest (vt ptk 2). Olen lisanud kursiivi märkimaks relatiivlauset ja selle põhja. 
luuakse referent üks vana inimene ja siis lisatakse selle referendi kohta täpsustus, mis sünnib, takerdudes enne relatiivlause põhisisu esitamist.

(7) mul on üks 'vana 'inimene kes on:=eee 'kae operat'siooni 'ühele=silmale teinud

Teine probleemiring, mis relatiivlausega seostub, on selle süntaktiline iseloom. Lähtudes eristusest restriktiivne/mitterestriktiivne, võime öelda, et restriktiivne relatiivlause on tüüpiline kõrvallause, mitterestriktiivne relatiivlause on aga pealausega nõrgemini seotud ja tal on rindlause omadusi (Erelt 2004; Erelt 2017: 740-742). Eestikeelses mitterestriktiivses relatiivlauses on harvem ka verbilõpuline sõnajärg, mis samuti näitab, et relatiivlause on pealausega nõrgemini seotud (Lindström 2004). Seega, restriktiivne relatiivlause moodustab oma põhjaga ühe fraasi (enamasti nimisõnafraasi), mitterestriktiivne aga ei moodusta sama tugevalt seotud tervikut. Samuti on näiteks soome keele puhul väidetud, et nimisõnafraas ei pruugi sugugi olla üheselt määratav (vt arutelu soome se että-alguliste konstruktsioonide kohta Suomalainen jt 2020). Kuna pole sugugi lihtne öelda, kumma relatiivlause tüübiga on tegemist, ega ka seda, mis on üks nimisõnafraas ja mis ei ole, tuleb siinkohal uuesti tõdeda, et relatiivlause funktsiooni tõlgendus ja süntaktiline käitumine ei ole (alati) üheselt määratavad.

Siinne artikkel on katse jõuda relatiivlause olemusele ja liigitusele lähemale eelkõige vestluses sündivate referentide viiteraamistiku kaudu. Põhifookuses on relatiivlause funktsioonid, mis sõltuvad põhjaks oleva nimisõnafraasi vormist ja infostaatusest käimasolevas vestluses. Metodoloogiliselt paigutub artikkel suhtluslingvistika raamistikku, mis analüüsib keelelisi üksusi suhtluse seisukohast, võttes arvesse üksuste ajalist järgnevust ja vestluspartnerite pidevat koostööd (vt nt Selting, Couper-Kuhlen 2001). See tähendab, et relatiivlauset vaadeldakse suhtluses ja suhtluse eesmärkide jaoks vestluse konkreetsel hetkel sündiva tarindina (vt ka Hopper 1987). Paljude tüüpidega ülevaade ei võimalda siiski esitada suhtluslingvistilistele uurimustele omaseid pikki vestluslõike ega arutleda täpsemalt selle üle, kuidas relatiivlaused igal konkreetsel juhul sünnivad. Seetõttu püüan siinkohal relatiivlauseid analüüsida eelkõige lähtuvalt põhja vormist ja (in)definiitsusest, jättes tagaplaanile selle, kuidas põhi ise on vestluses kujunenud. 


\section{Materjal}

Materjal on pärit Tartu Ülikooli suulise kõne korpusest. Kasutatud on selle alamkorpust, mille sisu on näha tabelis $1 .^{4}$ Alamkorpuses on peale suuliste spontaansete institutsionaalsete ja argidialoogide ka märgendatud dialoogiaktid, mida ei ole siinses artiklis kasutatud. Korpuse ja selle litereerimispõhimõtete kohta vt nt Hennoste jt 2009 ja Koit 2010.

Tabel 1. Kasutatud materjali ülevaade

\begin{tabular}{|l|c|c|}
\hline & Dialoogid & Sõned \\
\hline argivestlused & 44 & 20653 \\
\hline telefonivestlused, institutsionaalne & 893 & 123099 \\
\hline silmast silma, institutsionaalne & 99 & 39465 \\
\hline tee küsimine & 20 & 2936 \\
\hline kokku & 1056 & 186153 \\
\hline
\end{tabular}

Sellest materjalist on otsingumootori abil leitud pronoomenid kes ja mis kõikides käänetes ning pronoomenid kuhu, kus ja kust. Nendest on omakorda kokku kogutud kõik need juhud, kus loetletud pronoomenid alustavad relatiivlauset. Sellisel viisil sain 403 relatiivlauset, millest iga juurde määrasin põhja fraasitüübi ja relatiivlause restriktiivsuse/mitterestriktiivsuse. Analüüsi käigus grupeerisin relatiivlaused funktsiooni järgi tüüpidesse. Korpuse materjal võimaldas näha ka kogu relatiivlause konteksti, mida kasutasin põhja infostaatuse määramisel. Siinne artikkel on pigem kvalitatiivne ja arvulised näitajad on vaid illustratsiooniks selle kohta, kui palju mingit nähtust tegelikult esines.

\section{Relatiivlausete funktsioonid vastavalt põhja referentsetele omadustele}

Relatiivlause põhjaks olev fraas võib olla laiendatud määratlejaga (see, üks, mingi, selline jms, vt Pajusalu 2017), mida relatiivlause kontekstis on enamasti nimetatud korrelaadiks. Varemgi on osutatud, et korrelaadi olemasolu juhib tõlgendust pigem restriktiivsuse suunas ja et „mitterestriktiivse

4 Tänan korpuse kasutamise ja selgituste eest Olga Gerassimenkot, Tiit Hennostet, Mare Koitu, Andriela Rääbist ja Margus Treumuthi. 
lause põhjal korrelaati olla ei saa, sest põhi on juba määratud" (Erelt 2017: 741). Visapää (2012) leiab oma materjali põhjal siiski, et selliseid interpretatsiooni suunavaid korrelaate on tegelikus (soome) keelekasutuses suhteliselt vähe.

Artiklis analüüsingi materjalis esinenud fraase, mida relatiivlaused laiendavad. Alustan määratlejaga fraasidest, kuna nende referentne staatus on mõnevõrra selgem kui määratlejata fraasidel. Tabelis 2 on esitatud arvandmed kõikide põhjana esinenud fraasitüüpide kohta, lisaks kajastavad viimase tulba arvandmed restriktiivsete relatiivlausete esinemist rühmas.

Tabel 2. Relatiivlausete põhjade esinemus materjalis

\begin{tabular}{|c|c|c|}
\hline & Kokku & $\begin{array}{c}\text { Neist pigem } \\
\text { restriktiivseid }\end{array}$ \\
\hline määratlejata NP (111) & 111 & $50(45 \%)$ \\
\hline \multicolumn{3}{|l|}{ määratlejaga NP (160) } \\
\hline seeNP & 74 & $56(76 \%)$ \\
\hline üksNP & 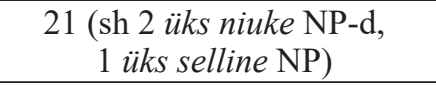 & $18(86 \%)$ \\
\hline mingiNP & $\begin{array}{c}22 \text { (sh } 4 \text { mingi selline } \mathrm{NP}-\mathrm{d}, \\
2 \text { mingi siuke } \mathrm{NP}-\mathrm{d}, \\
1 \text { mingi see } \mathrm{NP}, \\
3 \text { mingisugune } \mathrm{NP}-\mathrm{d}) \\
\end{array}$ & $19(86 \%)$ \\
\hline mõniNP & 5 & $5(100 \%)$ \\
\hline kõikNP & 4 (sh 3 kõik see NP-d) & $2(50 \%)$ \\
\hline $\begin{array}{l}\text { demonstratiivadjektiiviga } \\
\text { NP }\end{array}$ & $\begin{array}{c}28 \text { (sh } 5 \text { niisugune } \mathrm{NP}-\mathrm{d}, \\
2 \text { niuke } \mathrm{NP}-\mathrm{d}, 18 \text { sellineNP-d, } \\
3 \text { sihuke/siuke } \mathrm{NP}-\mathrm{d})\end{array}$ & $9(32 \%)$ \\
\hline muu kvantor NP & 6 & $5(83 \%)$ \\
\hline \multicolumn{3}{|c|}{ ainult pronoomenist või proadverbist koosnev NP (80) } \\
\hline see & $53(\operatorname{sh} 48$ see, 5 need $)$ & $50(94 \%)$ \\
\hline demonstratiivadverb & 11 & $11(100 \%)$ \\
\hline selline & 10 & $6(60 \%)$ \\
\hline kõik & 6 & $6(100 \%)$ \\
\hline \multicolumn{3}{|l|}{ põhjata (33) } \\
\hline nullpronoomen & 23 & $21(91 \%)$ \\
\hline $\begin{array}{l}\text { puudub } \\
\text { (vaba relatiivlause) }\end{array}$ & 10 & ei saa määrata \\
\hline \multicolumn{3}{|l|}{ muu (19) } \\
\hline KOKKU & 403 & \\
\hline
\end{tabular}


Restriktiivsete hulka on siin arvatud referenti valivad, loovad ja kinnitavad ning mitterestriktiivsete hulka referenti iseloomustavad, teemat jätkavad ja mittereferentsed relatiivlaused, mida käsitlen artiklis allpool täpsemalt.

\section{1. seeNP põhjana}

Nimisõnafraas määratlejaga see (seeNP) esines relatiivlause põhjana 74 korral. Nagu juba eespool öeldud, on pronoomenit see põhja osana peetud restriktiivse relatiivlause tunnuseks. Näites (8) ei ole selge, mis saatest või raamatust räägitakse, öeldes see saade või raamat, kuni pole lisatud relatiivlauset kus ta nagu ennast samastada saab. Referent piiritletakse kõikide võimalike saadete ja raamatute hulgast. Referent tekib siin põhja tähenduse ja relatiivlause piiritlemise koosmõjul. Traditsioonilise käsitluse järgi on selline relatiivlause restriktiivne, täpsemalt liigitan selle referenti loovaks relatiivlauseks.

(8) eks=see nii 'ikka 'öeldakse=et inimesele meeldib kõige rohkem 'see 'saade või 'raamat kus ta nagu ennast 'peategelasega 'samasta $=$ saab.

Tegelikes vestlustes on aga päris palju selliseid juhtumeid, kus põhi on laiendatud pronoomeniga see, relatiivlause on aga siiski mitterestriktiivne. Põhjus on pronoomeni see mitmefunktsioonilisuses: see võib olla ka definiitse NP määratleja (Pajusalu 1997) ja mitte olla seotud relatiivlausega. Sel juhul ei ole see relatiivlause korrelaat. Suhteliselt selge on see funktsioon definiitse määratlejana (ja mitte korrelaadina) nimede ees. Näite (9) relatiivlause mis on kolmetärnihotell ei saagi siin hulka piiritleda, sest põhi on definiitne ja ainukordne. Relatiivlause lisab hoopis uut infot hotelli kohta. Nimetan selliseid mitterestriktiivseid relatiivlauseid referenti iseloomustavateks (nagu ka Visapää 2012).

(9) ee 'samamoodi on väga: väga: 'hea on see hotell 'Rojal Palk'Park mis on 'kolmetärnihotell

Näite (10) puhul on varem räägitud tervisekindlustusest, mida nüüd uuesti nimetatakse. On põhjust arvata, et seda osutab siin fraasi definiitsusele. Kõneleja peab siiski oluliseks definiitsus veel relatiivlausega üle korrata. Relatiivlause sisu on ju ainult selles, et viidatu ongi see, millest vestluses ka varem räägiti. Seda on selles näites seega ühtaegu nii definiitsust osutav määratleja kui relatiivlause korrelaat. Võime relatiivlauset küll pidada 
restriktiivseks, kuid selle funktsioon on siin pigem meenutada, et sellest referendist on juba juttu olnud. Nimetan selliseid relatiivlauseid referendi definiitsust kinnitavateks.

(10) no tähendab see 'õnnetus ee='õnnetusjuhtumi kindlustus ilmselt mõeldakse seda 'tervisekindlustust millest ma 'alguses rääkisin

Mõnikord on siiski väga raske otsustada, kas see relatiivlause põhja ees on tingitud varasemast mainimisest ja seega referendi definiitsusest või sellest, et kõneleja planeerib jätkata relatiivlausega. Kindlasti annab aga seeNP ise väga hea võimaluse relatiivlauset edaspidise info esitamise jaoks kasutada. seeNP loob n-ö soodsa konteksti relatiivlause sünniks. Näites (11) on varem juba pikalt seletatud, mis on nõndanimetatud reisikindlustus. Nüüd viidatakse sellele uuesti ja üsna loomulik on kasutada siin määratlejat see. Relatiivlause lisab selle nõndanimetatud reisikindlustuse kohta uut infot ja on seega mitterestriktiivne. Näites (12) on tõenäoline, et kuulaja interpreteerib fraasi selle jutu definiitsena, sest varasema dialoogi põhjal on juba väga hästi tuvastatav, mis on see jutt. Kuna kõneleja siiski lisab ka (info poolest liigse) relatiivlause, on tagantjärele muidugi võimalik ka öelda, et see on siin korrelaat ja relatiivlause kuulub referenti loovate hulka. Tõenäolisem on siiski, et tegemist on definiitsust kinnitava relatiivlausega. Samuti kõneldakse näites (13) sellest üldprogrammist, mida on mainitud juba varasemas vestluses. Relatiivlause mis meil on aastaks annab üldprogrammi kohta lisainfot ega piiritle üldprogrammi teiste samasuguste hulgast (sest neid lihtsalt ei ole). Relatiivlause on seega referenti iseloomustav, samas ei ole ka seda võimatu tagantjärele restriktiivsena tõlgendada.

(11) siis on teil siis on tõesti targem juba võtta see nõndanimetatud 'reisikindlustus, mille kate on sada tuhat=e uuessaa 'dollarit?

(12) sis me saame muidugi 'telefoni teel 'ka 'kõik selle 'jutu ära \$ 'rääkida: mida me 'koosolekul 'räägime.

(13) näete siin on nüd se üldprogramm, mis meil on aastaks.

Materjali 74 seeNP hulgas oli vaid 13 sellist, kus see oli ainult definiitne määratleja, ja veel 5 sellist, kus see oli nii määratleja kui relatiivlause korrelaat. Võib siis öelda, et seeNP on tõesti tüüpiliselt restriktiivse, referenti loova relatiivlause põhjaks ja asesõna see funktsioon on neil juhtudel katafooriline, st see projitseerib ootuse, et järgneb relatiivlause. 
Siiski oli materjalis ligi veerandil juhtudest (täpsemalt 24\%) asesõna see funktsioon pigem juba tuntud referendi definiitsuse markeerimine ja see on viitesuhete seisukohast anafooriline.

\section{2. üksNP ja mingiNP põhjana}

Nimisõnafraas indefiniitse määratlejaga (üksNP ja mingiNP, nende hulgas ka mingisuguneNP) loob tüüpiliselt uue referendi, mida kuulaja ei saa varasemate teadmiste põhjal tuvastada (Pajusalu 2000). Sellist fraasi laiendav relatiivlause on mingis mõttes küll piiritlev, sest infot andes loomulikult ka vähendatakse võimalike referentide hulka. Pigem on siiski tegemist selle indefiniitse referendi kirjeldamisega (ja selle kaudu referendi loomisega) kui selle piiritlemisega teiste samasuguste hulgast. Näites (14) viitab referendile kõigepealt eksistentsiaallause subjekt $\ddot{u} k s$ diivanvoodi, seejärel lisatakse relatiivlausega selle oluline omadus. Kuna peale olemasolu ei olnud diivanvoodi kohta enne relatiivlauset midagi teada, siis mingis mõttes võib öelda, et relatiivlause piiritleb selle diivanvoodi nende diivanvoodite hulka, mis käivad lahti. Suhtluseesmärgina tundub siin siiski tähtsam diivanvoodi kohta info andmine, mille tagajärjel luuakse uus referent. Samuti on näites (15) relatiivlause funktsiooniks vajaliku info andmine ühe üksiku vanuri kohta, mitte vanurite hulga piiritlemine. Üht võib näidetes (14) ja (15) tõlgendada määratleja või numeraalina, kuid fraasid jäävad sellegipoolest indefiniitseks. Peale määratleja/ numeraali üks võib NP ees esineda ka veel mõni määratleja, nt niuke näites (16).

(14) kuigi toas on vähe mööblit et seal on üks diivanvoodi mis käib lahti hh ja .hhhhhhh lamp aga kaks sisseehitatud kappi on.

(15) mul on üks 'üksik 'vanur kellele 'tehti 'silmakae=operat'sioon 'ühele 'silmale.

(16) Põltsamaal peab olema üks niukene firma kes mü̈̈b kasutatud uksi

Referent võib olla ka täiesti üheselt tuvastatav, kuid esitatud partnerile indefiniitsena ning relatiivlausega antakse selle kohta uut infot. Näites (17) on klient tulnud kellassepa juurde, näitab kella (seega on see kell definiitne) ja esitab iseloomustava relatiivlause abil oma probleemi.

(17) mul on siin üks 'kell mis ei 'helise 
Relatiivlausega $\ddot{u} k s$ NP-dest oli enamik (21-st 18) just selliseid, mille puhul relatiivlause funktsioon oli luua koos põhjaga uut referenti. Ainult kolm näidet materjalis olid hoopis teistsugused: põhjaga viidatud referendi asemel oli relatiivlause fookuses sellega seotud üldine olukord. Näites (18) ei ütle relatiivlause kuhu me teeme grupireisi eriti midagi põhjaga viidatud Lõuna-Inglismaa kuurortlinna kohta ega näites (19) kus olid mitmekesised programmid eriti palju ühe aasta kohta, vaid pigem on nende puhul tegemist üldist teemat jätkavate relatiivlausetega.

(18) see saab 'olema ühte ühte=ee 'Lõuna-Inglismaa kuurort'linna, kuhu keelte'kooli, kuhu me 'teeme veel 'ühe selle grupi'reisi.

(19) sest 'oli 'üks aasta kus oli 'väga .hhhh 'mitmekesised prog'ramid aga 'on ka: 'on ka sellised kus on 'viis'teist 'tundi, .hhh 'pljuss pljus mõned ekskursi'oonid

mingiNP on mõnikord sarnaselt $\ddot{u} k s \mathrm{NP}$-ga indefiniitse referendi esimeseks maininguks. Neil juhtudel (materjalis kokku 5) oli ka relatiivlause funktsioon sarnane eespool $\ddot{u} k s \mathrm{NP}$-de puhul kirjeldatuga: uue referendi kohta info andmine ja selle abil uue referendi loomine. Näites (20) viitab kõneleja numbrile, mis kuulajale on tundmatu, kuid tegelikult täiesti spetsiifiline ning mille kohta annab ta seejärel relatiivlausega lisainfot.

(20) ja ma 'helistasin mingil 'numbril mis oli: 'rahvusvaheliste 'rongireiside 'number.

Enamasti esinesid mingiNP-d aga küsivates kontekstides, kus nad viitasid ebaspetsiifilisele referendile, mille olemasoluski kõneleja kindel ei ole. Referent luuakse alles mingiNP ja relatiivlause koosmõjul ehk relatiivlause loob koos oma põhjaga referendi (21).

(21) kas te 'teate kas=se Tähe tänaval 'Tartus 'on mingi see 'number kus on nagu 'pesumasinate ja parandus'töökoda mingi=vä

mingiNP-sid oli materjalis kokku 22, millest 14 viitasid indefiniitsetele ebaspetsiifilistele ja indefiniitsetele referentidele, mis loodi mingiNP ja relatiivlause koostöös.

Näited (22) ja (23) erinevad eespool käsitletutest selle poolest, et üks ja mingi ei laienda viitavat, vaid iseloomustavat fraasi, mis on pealauses öeldistäide. Sellises kontekstis ei saagi formaalselt esineda restriktiivset relatiivlauset, sest selle põhi ei viita, see tähendab, et justkui pole, mida piiritleda. Küll aga laiendab relatiivlause sisuliselt ka lause subjekti (vastavalt 
jõulukaktus ja need) ja funktsiooni poolest on need relatiivlaused referenti iseloomustavad. Nimetan neid siiski mittereferentseteks relatiivlauseteks. Selliseid oli üksNP-de hulgas üks ja mingiNP-de hulgas kolm.

(22) näiteks 'jõulukaktus on üks selline mis ['ültse] 'pööramist ei taha

(23) me oleme siin 'Eestis harjunud=et=kui on nagu mingi 'rahvus'toit=sis ned on nagu mingi 'körtpärtli 'särk mida 'süia ei saa.

\subsection{Kvantoriga NP-d põhjana}

NP määratleja positsioonis võivad olla ka kvantorid. Siinses materjalis esinesid ainult kõik ja mõni. kõikNP-d leidus neli korda, neist kolmel korral oli fraasis ka teine määratleja see. Kahel korral viitas kõikNP juba varem definiitsele referendile. Näites (24) toimub vestlus kodumasinate poes, kus kõneldakse müügil olevatest pesumasinatest. Relatiivlause pigem kinnitab definiitsust, kui annab referendi kohta mingit uut infot. Näites (25) vesteldakse ülikoolis õppekava täitmisest ja siin luuakse referent (kõik need kõrvalained) alles relatiivlausega.

(24) kõik masinad mis meil 'on, tahavad saada 'külma 'vett.

(25) kas 'on kõik need ained 'kuulatud mida nemad .hh nagu 'kõrvalaine puhul 'eeldavad.

mõni $\mathrm{NP}$ on sarnane eespool käsitletud mingiNP-ga, kuna esineb eelkõige ebaspetsiifilistes (küsivates) kontekstides (viiest mõniNP-st oli neli sellist). Näite (26) voor on küsimus infotelefonile. Relatiivlause määratleb, mis telefoninumbrit tahetakse. Ühel juhul viitas mõniNP uuele spetsiifilisele mitmuslikule referendile (27). mõniNP loob mõlemas siinses näites referendi koostöös relatiivlausega.

(26) .hh 'oskate te ehk 'öelda Tartus:=e mõnda telefoni'numbrit 'kus 'tegeldaks vanurite 'abistamisega

(27) mõned firmad kes=seal veel 'Rovaniemis mingisugused paar tunnikest 'peatuvad, .hh need selle=eest peavad siis öö=läbi 'sõitma 


\subsection{Demonstratiivadjektiiviga NP põhjana}

Suhteliselt suur rühm relatiivlause põhjadest olid demonstratiivadjektiiviga laiendatud NP-d (kokku 28). Materjalis esinesid niisugune, niuke, selline, sihuke ja siuke. Osa seda tüüpi NP-sid (materjalis 11 juhtu) ei olnud referentsed, vaid esinesid predikatiivina definiitse referendi iseloomustamisel lausetüübis see/NP on sellineNP, mis ..., nagu näites (28). Relatiivlause kirjeldab siin tegelikult mitte oma põhja, vaid sellele eelnenud subjektifraasi see referenti, olles oma funktsioonilt eelkõige iseloomustav. Liigitasin need juhud siiski mittereferentsete hulka.

(28) et $\mathrm{se}=\mathrm{on}=$ nüd selline: ee 'selline auto millel on 'võimalus sis \{juba rohkem\} 'pagasit vedada, 'istet alla lasta, ütleme siukse ak'tiivse elu jaoks võibla e isegi atrak'tiivsem kui=nüt on se'daan.

Teine grupp (9 juhtu) demonstratiivadjektiiviga tarindeid on sellised, kus DemAdjNP viitab ebaspetsiifilisele referendile, kas siis küsimuses (nt kas selline... on olemas?) või muus ebaspetsiifilises kontekstis. Relatiivlause väljendab sel juhul selle referendi omadusi, mis teevad potentsiaalse referendi olukorra jaoks sobivaks. Näites (29) ütleb kõneleja, et soovib (ebaspetsiifilist) niukest kena korterit, mille omadus selgub relatiivlauses ( $k u s$ oleks hea elada). Liigitasin selle näite referenti loovaks relatiivlauseks.

(29) mt et 'tahaks 'just niukest 'kena \$ 'korterit=et kus oleks nagu 'hea elada $=$ et niuke 'kodutunne tuleks.

Kaheksal juhul oli DemAdjNP referentne, relatiivlausega esitati referendi omadus. Näites (30) on põhjaks sellised värvid, mille referent on olukorras nähtaval ja seega definiitne, relatiivlause on selgelt iseloomustav. Tõenäoliselt kaasneb fraasiga sellised värvid ka osutav žest, mis teeb selle fraasi multimodaalseks (vt multimodaalsete nimisõnafraaside kohta Keevallik 2020). Sama keelelise struktuuriga põhi (aga ilma osutava žestita) võib aga olla ka restriktiivne, mille puhul relatiivlause loob referendi (31).

(30) siin on sellised 'värvid mis noh ütleme hallikat 'tooni annavad

(31) ja on kohe 'koos selline preparaat kus on ned ee 'vitamiinid koos 'mineraalainetega 


\subsection{Pronoomen, proadverb või kvantor põhjana}

Relatiivlause põhjana võib esineda ka demonstratiivpronoomen või -proadverb, samuti kvantor. Väga sage juhtum materjalis oli selline, kus relatiivlause laiendas üksi esinevat pronoomenit see (53 juhtu). Pronoomeni referent selgus peaaegu alati koosmõjus relatiivlausega, seega oli enamasti tegemist referenti loovate relatiivlausetega. Vaid üksikutel juhtudel võis pronoomen see viidata referendile, mis on juba sellisena vestluses esinenud ja seega definiitne.

Enamasti viitas see millelegi, mis on olukorras nähtaval või kõne all olnud, kuid relatiivlause piiritles referendi konkreetsemaks ja täpsemaks. Sellises kontekstis oli relatiivlause kindlasti restriktiivne. Näites (32) valitakse poes kella ja relatiivlause aitab pronoomeniga see viidatud kella täpsemalt tuvastada. Näites (33) on kõneldud reisidest üleüldse, relatiivlause mis Soomest algusega on piiritleb reiside hulga. Näide 33 esindab ka materjalis üsna sagedat relatiivlausega lahktarindit (vt ka Amon 2015; Laury, Helasvuo 2016).

(32) võib me'tallkett olla näiteks see nagu see mis seal on see kolmsada

(33) need mis 'Soomest algusega on need on 'viimase hetke reisid on suhtselt 'soodsa pakkumisega.

Suhteliselt harva esines selliseid juhtumeid, kus asesõnaga see viidatu oli juba varem kõne all olnud ja relatiivlause ainult kinnitas referendi definiitsust (34).

(34) need on nagu mis ma präegu ütsin need on ka sellised 'soodushinnad

Mõnikord on tegemist abstraktse referendiga, mis sõnastatakse alles relatiivlausega, ja pronoomen see on n-ö puhas korrelaat, mis toimib katafoorina ehk saab referentse sisu alles hiljem relatiivlauses (35).

(35) et noh oleneb muidugi sellest mis neil see 'miinimum inimeste 'arv on.

Materjalis oli 11 lauset kujul kes X see Y (kes tahab, see läheb; mis meelel, see keelel), mis eristuvad tüüpilisest relatiivlausest sellega, et siin esineb relatiivlause enne oma põhja. Sellised relatiivlaused on küll referenti piiritlevad ja seega restriktiivsed, kuid nende suhtluseesmärk pole ilmselt üldse referentne, vaid pigem on öeldul idiomaatiline tähendus. Samas võib sellisel konstruktsioonil olla ka referentne tõlgendus, nagu näites (36), kus viidatakse lastele, kes käivad lasteaias. 
(36) kes lähevad 'lasteaeda need 'hommikuti 'käia ei='saa

Demonstratiivadverbid olid relatiivlause põhjaks 11 korral, sel juhul oli relatiivpronoomeniks alati kus/kust (mis võis esineda ka teiste põhjade puhul). Kõikidel juhtudel oli relatiivlauset võimalik tõlgendada restriktiivsena (ja referenti loovana). Näites (37) määratleb relatiivlause koha, relatiivlause põhi seal on katafoorne ja referent kujuneb alles pärast relatiivlauset.

(37) .hhh ma mõtlen just seal kus see suur 'kaubamaja, .hhh nende 'esindus on 'seal.

Kõik oli põhjaks viiel korral. Kõik need olid sellised juhud, kus põhi koos relatiivlausega lõi ühe tervikliku referendi, nagu näites (38). Kõik erineb asesõnaga see viidatust eelkõige selle poolest, et kannab endas pragmaatilise rohkuse tähendust (Pajusalu 2008).

(38) 'laulmine e laulu'mängud, näpu'mängud, 'kõike mida saab 'teha

Proadjektiiv selline oli põhjaks kümnel korral. Neist neljal juhul oli selline predikatiivi funktsioonis, mistõttu oli see pigem mittereferentne (39). Kolmel korral oli tegemist ebaspetsiifilise kontekstiga (40) ja kolmel spetsiifilise viitava fraasiga, milles pronoomen ja relatiivlause moodustasid ühe tervikliku viiteüksuse ning relatiivlause oli seega referenti loov (41).

(39) see on nüüd näiteks 'selline mis mis ee: on küll 'niisutav aga natuke 'uutmoodi niisutav kreem kui need 'tavalised

(40) 'kas 'teie 'võite mulle 'kulla inimene 'öelda='mis:='on 'meil 'Tartu 'linnas 'sellist 'kus='saab .hhh 'endale 'karnevali kos'tü̈̈me laenutada

(41) mul on 'sellist millega sa võid värvida 'nii 'seest kui 'väljast.

\subsection{Määratlejata NP põhjana}

Suur rühm relatiivlause põhjasid on määratlejata nimisõnafraasid (NP), kokku oli neid materjalis 111. Nende hulgas oli omakorda selline suur rühm, kus NP ise on definiitne, mistõttu seda ei saa kuidagi rohkem piiritleda ja relatiivlauset saab pidada selgelt mitterestriktiivseks. Üks võimalus selliseks definiitsuseks on unikaalsus - NP on nimi või nimetus. Näites (42) on selline Põlva õppekeskus, mida infotelefoni töötaja ilmselt oma andmestikus näeb. Teine võimalus definiitsuseks on NP referendi tuvastatavus varasema diskursuse ja maailmateadmiste põhjal. Näites (43) nimetab 
kõneleja garaažikatust, mille kohta väidab seejärel, et see vajab remonti. Näites (44) öeldakse, et reisile läheb kaasa reisijuht, kes reisil teenindab. NP-d garaažikatus või reisijuht ei ole küll definiitsed selles mõttes, et neist oleks varem räägitud, kuid samas ei saa ka öelda, et relatiivlause piiritleks referenti. Selline relatiivlause laiendab sageli eksistentsiaal- või omajalause subjekti. Taas on tegemist funktsiooni poolest mitterestriktiivsete, iseloomustavate (või ka teemat jätkavate) relatiivlausetega.

(42) meil näitab 'Põlvas:=e v='Põlva õppe'keskus mis kuulub 'Keskeesti 'arenduskeskuse alla.

(43) H: hh teil oli üks 'kuulutus e teete katuse 'remonti.

$\mathrm{V}$ : jaa on 'küll=jah. (0.5)

$\mathrm{H}$ : e on garaaži 'katus, mis vajaks 'remonti $=\mathrm{ja}$ võiks siis 'võtta $\mathrm{ka}=\mathrm{vel}:=\mathrm{e}$ tema 'ülekatmise.

(44) meilt on kaasas siis ee nii=öelda 'reisi 'juht kes: e kes siis selle ne- selle reisi teile ka ilusti nimodi. hhh ee 'kandikul ette toob

Grammatiliselt põhjaks olev NP võib tegelikult semantiliselt mitte moodustada relatiivlausega referentset tervikut, relatiivlause jätkab käimasoleva vestluse sisu. Näites (45) ei mõjuta relatiivlause otseselt referendi Meritsa tõlgendust ${ }^{5}$, pigem on relatiivlause infojagamisel põhja külge grammatiliselt seotud. Põhjaks olev NP võib olla mittereferentne, ka sel puhul ei saagi relatiivlause olla restriktiivne. Näites (46) viitab fraas maal eelkõige eluviisile, mitte elukohale. Relatiivlause iseloomustab seda elamisviisi täpsemalt.

(45) siis ee sõidetakse 'kolmandal päeval $\{--\}$, sealt 'järgmisel päeval Meri'tsasse, ee 'kus: käiakse Kastilla püramiidi 'kompleksis $=j a\{-\}$ 'sõdurite templis.

(46) ja vaata 'paljud 'üliõpilased on siiski ka 'maalt 'pärit, kus on nagu nagu: 'pensionärist=eeeeee vaa- 'vaarvanematel 'kindlasti väike 'põllulapp.

Tüüpilised restriktiivsete relatiivlausete juhtumid on sellised, kus NP annab ebaspetsiifilise referendi, mida siis relatiivlause täpsustab. Näites (47) nimetatakse patsienti, keda on vaja täpsemalt iseloomustada, et

\footnotetext{
5 Näide 45 illustreerib ka seda, kuidas relatiivlausega saab n-ö taktitundeliselt infot jagada (vt Loock 2007: 353): kui kuulaja teadis, et Meritsas on püramiidid ja tempel, siis tõlgendab ta lauset lihtsalt reisikirjeldusena, aga kui ei teadnud, siis võis kuulaja selle info oma teadmistesse lisada.
} 
tema isik selgeks teha. Näites (48) küsitakse toonide tabelit, mis jääb kõneleja arvates ilmselt liiga ebaspetsiifiliseks, sest ta laiendab seda relatiivlausega kus saab näha ... Relatiivlause on siin restriktiivne selles mõttes, et täpsustab, millist toonide tabelit mõeldi, ehk piiritleb kõikide võimalike toonide tabelite hulgast selle, mida tal vaja on. Samas tundub see näide informatsiooniliselt ebavajalikuna: mis toonide tabeleid siis veel peaks olema? Võime ka öelda, et relatiivlause ei väljenda siin mitte ainult referendi piiritlemist (kuigi ka seda ei saa eitada), vaid pigem õigustust oma küsimusele (seda võiks nimetada ka ,relevantsust osutavaks relatiivlauseks“, vt Loock 2007). Sarnane on näide (49), milles soovitakse reisibüroos tutvuda reisidega mis teil on (nagu oleks võimalik tutvuda reisidega, mida ei ole), mis samuti muudab pigem soovi relevantseks, kui lisab mingit olulist infot. Selline interpretatsioon on aga omane eelkõige mitterestriktiivsetele relatiivlausetele.

(47) ma võiks saada 'infot 'patsiendi 'kohta kellele täna 'kopsu ee tändap=mhh ee 'selgroo operatsiooni pidi 'tehtama

(48) $\mathrm{kas}=$ teil=on 'toonide tabel 'ka=et et kus saab 'näha et 'kaks tooni heledamaks.

(49) ee ma sooviksin 'tutvuda: 'reisidega mis teil 'on.

\subsection{Vabad relatiivlaused}

Viimasena vaatleme selliseid relatiivlause struktuuriga üksusi, millel ei ole põhja. Kokku oli neid materjalis 33. Osa neist olid vabad katked, mis ei ole alistatud ühelegi teisele lausele, mõned aga sellised, kus võiksime põhjaks pidada mõnd elliptilist lauseliiget, mida on võimalik juurde mõelda. Näites (50) ei ole relatiivlausele kes tahab minna sinna löbustusparki lihtne juurde mõelda süntaktiliselt seotud põhja. Kas selline fraas on referentne, on vaieldav, kuid see võib siiski viidata mingile ebaspetsiifilisele rühmareferendile. Ka näidetes (51) ja (52) on tegemist sama tüüpi ebaspetsiifilise grupireferendiga, kuid seal on võimalik pealausesse juurde mõelda põhjad need ja nendele. Need relatiivlaused saab ehk liigitada restriktiivseteks, sest nad piiritlevad ja loovad uue referendi, kuid teevad seda üksi, ilma põhja toeta. Kokku oli selliseid ebaspetsiifilisele rühmareferendile viitavaid relatiivlauseid 14 , neist enamik esines reisibüroodes peetud vestlustes. 
(50) V: ja 'lisatasu eest on sis 'see mis on nagu seal lisatasu 'punkti all kirjas. $(0.5)$

$\mathrm{H}: \mathrm{mt}$ ja et 'mis see $=$ on mis $=$ seal $=$ ' on $[$ siis $\{-\}]$

V: [see Santa]'park, (.) väikelastele, kes tahab 'minna sinna 'lõbustusparki [Santaparki.]

(51) $\mathrm{H}$ : .hh siis ma tahtsin vel 'küsida=et 'kuidas seda 'palka nagu 'arvestatakse

$\mathrm{V}$ : =see 'palk on 'kilode pealt. 'nii palju marju $\{-\}$ kes on marju korjand 'teavad juba.

(52) teinekord noh päris 'paljud 'alati lähevad 'sõpradega \$ 'ka 'koos=e \$ .hhhh 'e:t=et=et et 'kes, 'kes 'soovivad koos 'sõpradega nagu 'majutust et=sis=me nagu alati: seda 'võimaldame=aga aga 'muidu me 'paigutame nad nagu: 'tavaliselt

Suhteliselt selgepiirilise rühma põhjata relatiivlauseid moodustasid kus-algulised relatiivlaused, mis määratlesid telefoninumbrit (infotelefoni kõnedes, (53)) või mingit toodet (54), kokku seitse juhtu. Näidet (54) võiks pidada üheks harvadest referenti valivatest restriktiivsetest relatiivlausetest, kuna relatiivlausega tuvastatakse siin varem esitletud referentidest üks.

(53) ee: 'ma=tahaks=e $k u s=s e$ 'autu. hh ee $\mathrm{mm}$ autusid re'monditakse autoremont'töökojad, $. \mathrm{hh} \mathrm{phh}=$ ee neid ee 'mootoreid=ja

(54) siis võiks 'võtta kus on ka see 'žennženni='ekstrakt 'sees

\section{Kokkuvõte}

Artiklis analüüsisin eesti suuliste vestluste relatiivlauseid, lähtudes eelkõige nende suhtlusfunktsioonist ja põhja struktuurist. Soome keele relatiivlausete funktsioone uurides on nt Laura Visapää (2012: 533) väitnud, et restriktiivse ja mitterestriktiivse relatiivlause puhul võime rääkida ühest konstruktsioonist, mis saab eri kontekstides erinevaid interpretatsioone. Sellega võib igati nõus olla ka eesti keele puhul, sest tõepoolest ei ole kindlat süntaktilist malli, mis määraks ära relatiivlause funktsiooni. Siiski, kui vaadelda relatiivlauseid koos infostaatuse seisukohast analüüsitud põhjaga, on võimalik välja tuua tüüpilisi konstruktsioone.

Pigem restriktiivsete relatiivlausete hulka võiks paigutada järgmised alltüübid. 
A. Referenti valiv relatiivlause, mille abil tuvastatakse referent juba tuntud referentide hulgast. See tüüp oli materjalis üsna haruldane, kuid võib olla valdav teist tüüpi suulises suhtluses, kus keskendutakse referentide valikule nähtavate või muul viisil tuvastatavate referentide hulgast.

(54) siis võiks 'võtta kus on ka see 'žennženni='ekstrakt 'sees

B. Definiitsust kinnitav relatiivlause, mis kuulub referentide tuvastamist reguleerivate vahendite hulka ja mida võiks lugeda ka vestlusanalüüsis parandusmehhanismina käsitletavate nähtuste osaks.

(10) no tähendab see 'õnnetus ee='õnnetusjuhtumi kindlustus ilmselt mõeldakse seda 'tervisekindlustust millest ma 'alguses rääkisin

C. Referenti loov relatiivlause, mille abil määratletakse põhja poolt üldsõnaliselt nimetatud referent. Referent tekib alles pärast põhja laiendamist relatiivlausega. Referentsuse poolest jaguneb rühm omakorda kaheks vastavalt sellele, kas referent on spetsiifiline (41) või ebaspetsiifiline (21). Ebaspetsiifilised referenti loovad relatiivlaused on tüüpiliselt seotud põhjadega, milles esineb mingi või mõni.

(41) mul on 'sellist millega sa võid värvida 'nii 'seest kui 'väljast.

(21) kas te 'teate kas=se Tähe tänaval 'Tartus 'on mingi see 'number kus on nagu 'pesumasinate ja parandus'töökoda mingi=vä

Pigem mitterestriktiivsete relatiivlausete hulgas ilmnesid materjalis järgmised tüübid, millest kaks esimest on olnud eraldi tüüpidena ka Loocki (2007) ja Visapää (2012) uurimustes (kuigi nende tüüpide vaheline piir on paljudel juhtudel hägus).

D. Referenti iseloomustav relatiivlause, mis annab juba tuvastatud referendi kohta uut infot.

(17) mul on siin üks 'kell mis ei 'helise

E. Teemat jätkav relatiivlause, mis ei iseloomusta referenti, millega on ta grammatiliselt seotud, vaid lisab käimasolevasse vestlusse uut infot.

(18) see saab 'olema ühte ühte=ee 'Lõuna-Inglismaa kuurort'linna, kuhu keelte'kooli, kuhu me 'teeme veel 'ühe selle grupi'reisi. 
F. Mittereferentsed relatiivlaused, mis ei laienda viitavat, vaid kirjeldavat fraasi. Selliseid leidus eriti palju sellineNP-de hulgas.

(28) et $\mathrm{se}=\mathrm{on}=$ nüd selline: ee 'selline auto millel on 'võimalus sis \{juba rohkem\}' 'pagasit vedada, 'istet alla lasta, ütleme siukse ak'tiivse elu jaoks võibla e isegi atrak'tiivsem kui=nüt on se'daan.

Relatiivlause põhjana esines pea pooltel juhtudel määratlejaga nimisõnafraas (seeNP, üks NP, mingiNP jms), umbes veerandil juhtudest määratlejata nimisõnafraas ja viiendikul juhtudest ainult pronoomen, proadverb või proadjektiiv (see, seal, selline jms). Umbes $8 \%$ relatiivlausetest esines ilma põhjata. Ükski põhja tüüp aga ei signaliseeri üheselt, millist tüüpi relatiivlause talle järgneb: see sõltub ikkagi kogu kontekstist. Ka nende põhja tüüpide puhul, millel tabelis 2 on kirjas $100 \%$ restriktiivseid relatiivlauseid, ei pruugi see tuleneda võimatusest kasutada mitterestriktiivset relatiivlauset, vaid pigem piiratud materjalihulgast.

Relatiivlausete süntaktiliseks omaduseks oli paiknemine pärast pealauset ja enda laiendatavat põhja, kusjuures pealauseks oli tihti kas eksistentsiaal- või omajalause, mille subjekt on lause lõpus. Samuti laiendas relatiivlause sageli objekti või predikatiivi, mis samuti paiknevad lause lõpus. Kuna neid lausetüüpe oli materjalis väga palju, torkas silma olemaverbi rohkus relatiivlause pealausetes. See aspekt, nagu paljud muudki artiklis lühidalt mainitud seaduspärasused, nõuaks siiski omaette käsitlust.

\section{Kirjandus}

Amon, Marri 2015. Initial and Final Detachments in Spoken Estonian: A Study in the Framework of Information Structuring. (= Dissertationes Linguisticae Universitatis Tartuensis 24.) University of Tartu.

Andrews, Avery D. 2007. Relative clauses. - Language Typology and Syntactic Description. Vol. II: Complex Constructions. 2nd edition. Ed. by Timothy Shopen. Cambridge: Cambridge University Press, 206-236. https://doi. org/10.1017/CBO9780511619434.004

Busch, Jerra Lui, Felix Schumann 2016. Unspecific indefinites and (non-) restrictive relative clauses. - Lingua 181, 1-35. https://doi.org/10.1016/j. lingua.2016.04.005

Comrie, Bernard 1989. Language Universals and Linguistic Typology: Syntax and Morphology. 2nd edition. Chicago: University of Chicago Press.

Erelt, Mati 2004. Märkmeid eesti keele komplekslause kohta. - Keel ja Kirjandus $6,401-413$. 
Erelt, Mati 2017. Liitlause. - Eesti keele süntaks. Toim. Mati Erelt, Helle Metslang. (= Eesti keele varamu III.) Tartu: Tartu Ülikooli Kirjastus.

Dahl, Östen, Maria Koptevskaja-Tamm (eds.) 2001. Circum-Baltic Languages. Vol. 1: Past and Present. John Benjamins Publishing Company. https:// doi.org/10.1075/slcs.54

Givón, Talmy 1983. Topic Continuity in Discourse: A Quantitative Cross-Language Study. Amsterdam: John Benjamins. https://doi.org/10.1075/tsl.3

Givón, Talmy 2005. Context as Other Minds. The Pragmatics of Sociality, Cognition and Communication. Amsterdam, Philadelphia: John Benjamins Publishing Company. https://doi.org/10.1075/z.130

Gundel, Jeanette, Nancy Hedberg, Ron Zacharski 2019. Cognitive status and the form of referring expressions in discourse. - The Oxford Handbook of Reference. Ed. by Jeanette Gundel, Barbara Abbott. Oxford: Oxford University Press, 67-99. https://doi.org/10.1093/ oxfordhb/9780199687305.013.5

Helasvuo, Marja-Liisa 1993. Are relative clauses either restrictive or non-restrictive? A study of the relative clauses in the Finnish pear stories. - Case and Other Functional Categories in Finnish Syntax. Ed. by Anders Holmberg, Urpo Nikanne. New York, Berlin: Mouton de Gruyter, 163-176. https:// doi.org/10.1515/9783110902600.163

Hennoste, Tiit, Olga Gerassimenko, Riina Kasterpalu, Mare Koit, Andriela Rääbis, Krista Strandson 2009. Suulise eesti keele korpus ja inimese suhtlus arvutiga. - Eesti Rakenduslingvistika Ühingu aastaraamat 5. Toim. Helle Metslang, Margit Langemets, Maria-Maren Sepper, Reili Argus. Tallinn: Eesti Keele Sihtasutus, 111-130. http://dx.doi. org/10.5128/ERYa5.07

Hoek, Jet, Hannah Rohde, Jacqueline Evers-Vermeul, Ted J. M. Sanders 2021. Scolding the child who threw the scissors: Shaping discourse expectations by restricting referents. - Language, Cognition and Neuroscience 36 (3), 382-399. https://doi.org/10.1080/23273798.2020.1852292

Hopper, Paul 1987. Emergent grammar. - Berkeley Linguistics Society 13, 139-157. https://doi.org/10.3765/bls.v13i0.1834

Keenan, Edward L. 1985. Relative clauses. - Language Typology and Syntactic Description. Vol. II: Complex Constructions. Ed. by Timothy Shopen. Cambridge: Cambridge University Press, 141-170.

Keevallik, Leelo 2020. Multimodal noun phrases. - The 'Noun Phrase' across Languages: An Emergent Unit in Interaction. Ed. by Tsuyoshi Ono, Sandra A. Thompson. (= Typological Studies in Language 128.) Amsterdam: John Benjamins Publishing Company, 154-177. https://oi.org/10.1075/ tsl.128.07kee 
Kibrik, Andrey A. 2011. Reference in Discourse. Oxford: Oxford University Press. https://doi.org/10.1093/acprof:oso/9780199215805.001.0001

Koit, Mare 2010. Eesti dialoogikorpus ja argumenteerimisdialoogi arvutil modelleerimine. - Keel ja Kirjandus 4, 241-262.

Laury, Ritva, Marja-Liisa Helasvuo 2016. Detached NPs with relative clauses in Finnish conversations. - Information Structuring of Spoken Language from a Cross-linguistic Perspective. Ed. by M. M. Jocelyne FernandzVest, Robert D. Van Valin, Jr. (= Trends in Linguistics. Studies and Monographs 283.) Berlin, Boston: De Gruyter Mouton, 149-166. https:// doi.org/10.1515/9783110368758-008

Lindström, Liina 2004. Verbi asend eesti kõrvallauses. Relatiivlaused. - Keel ja Kirjandus 6, 414-429.

Loock, Rudy 2007. Appositive relative clauses and their functions in discourse.Journal of Pragmatics 39 (2), 336-362. https://doi.org/10.1016/j. pragma.2006.02.007

Pajusalu, Renate 1997. Is there an article in (spoken) Estonian? - Estonian: Typological Studies II. Ed. by Mati Erelt. Tartu: Tartu Ülikooli eesti keele õppetool, 146-177.

Pajusalu, Renate 2000. Indefinite determiners mingi and $\ddot{u} k s$ in Estonian. - Estonian: Typological Studies IV. Ed. by Mati Erelt. Tartu: Tartu Ülikooli Kirjastus, 87-117.

Pajusalu, Renate 2008. Pragmatics of quantifiers: The case of Estonian kõik 'all'. - Journal of Pragmatics 40 (11), 1950-1965. https://doi. org/10.1016/j.pragma.2008.04.006

Pajusalu, Renate 2017. Nimisõnafraas. - Eesti keele süntaks. Toim. Mati Erelt, Helle Metslang. (= Eesti keele varamu III.) Tartu: Tartu Ülikooli Kirjastus, 379-404.

Pajusalu, Renate, Maria Reile, Helen Hint, Tiina Nahkola, Piia Taremaa 2018. Relative clauses in spatial and narrative contexts in Estonian, Finnish, and Russian. - SKY Journal of Linguistics 31, 107-142.

Pikver, Ann 1988. Eesti relatiivlausest keeletüpoloogilisel taustal. - Keel ja Kirjandus 7-8, 392-397, 486-493.

Pook, Hanna 2019. The pronoun kes 'who' and its referent's animacy in Estonian dialects. - SKY Journal of Linguistics 32, 105-144.

Pääkkönen, Irmeli 1988. Relatiivisanan valinta. Helsinki: Suomalaisen Kirjallisuuden Seura.

Schubö, Fabian, Anna Roth, Viviana Haase, Caroline Féry 2015. Experimental investigations on the prosodic realization of restrictive and appositive relative clauses in German. - Lingua 154, 65-86. https://doi. org/10.1016/j.lingua.2014.11.006 
Selting, Margret, Elisabeth Couper-Kuhlen 2001. Studies in Interactional Linguistics. Philadelphia: John Benjamins Publishing Company. https:// doi.org/10.1075/sidag. 10

Stoenica, Ioana-Maria, Simona Pekarek Doehler 2020. Relative-clause increments and the management of reference: A multimodal analysis of French talk-in-interaction. - Emergent Syntax for Conversation: Clausal Patterns and the Organization of Action. Ed. by Yael Maschler, Simona Pekarek Dohler, Jan Lindström, Leelo Keevallik. (= Studies in Language and Social Interaction 32.) Amsterdam: John Benjamins Publishing Company, 303-329. https://doi.org/10.1075/slsi.32.11sto

Stoenica, Ioana-Maria, Simona Pekarek Doehler, Anne-Sylvie Horlacher 2020. Emergent complex noun phrases: On-line trajectories of "relativized" NPs in French talk-in-interaction. - The 'Noun Phrase' across Languages: An Emergent Unit in Interaction. Ed. by Tsuyoshi Ono, Sandra A. Thompson. (= Typological Studies in Language 128.) Amsterdam: John Benjamins Publishing Company, 43-70. https://doi.org/10.1075/ tsl.128.03sto

Suomalainen, Karita, Anna Vatanen, Ritva Laury 2020. The Finnish se että initiated expressions: NPs or not? - The 'Noun Phrase' across Languages: An Emergent Unit in Interaction. Ed. by Tsuyoshi Ono, Sandra A. Thompson. (= Typological Studies in Language 128.) Amsterdam: John Benjamins Publishing Company, 12-41. https://doi.org/10.1075/ tsl.128.02suo

Velupillai, Viveka 2012. An Introduction to Linguistic Typology. John Benjamins Publishing Company. https://doi.org/10.1075/z.176

Visapää, Laura 2012. Joka-relatiivilauseen tulkinnasta. - Virittäjä 116 (4), 533-559. 


\title{
Relative clauses in spoken Estonian as referential devices
}

\author{
RENATE PAJUSALU
}

In this article, the usage of relative clauses in spoken Estonian in the overall framework of referential devices is studied. The data come from the corpus of spoken Estonian (University of Tartu), and contain relative clauses beginning with the relativizers mis 'that (non-animate)', kes 'that (animate)' and kus 'that, where' (in all grammatical cases). The collected data (403 relative clauses from institutional and non-institutional conversations) were analysed according to the types of head NP (including bare NPs, NPs with determiners, demonstratives, quantifiers, zero reference).

The analysis revealed that relative clauses (RC) in the data could be divided into six main types: referent-choosing RC, referent-creating RC (in specific and non-specific contexts) and referent-confirming $\mathrm{RC}$ could be treated as restrictive $\mathrm{RC}$; referent-characterizing RC, continuative $\mathrm{RC}$, and non-referential RC could be treated as appositive RC. The analysis also revealed that no type of head NP is strictly related to any type of RC.

Keywords: relative clause, noun phrase, determiners, reference

Renate Pajusalu

Eesti ja üldkeeleteaduse instituut

Tartu Ülikool

Jakobi 2

51014 Tartu

renate.pajusalu@ut.ee 